\title{
Krig og kunst, æstetisering og stat
}

Joanna Bourke (red.): War and Art: A Visual History of Modern Conflict. London: Reaktion Books 2017, 392 sider, $339 \mathrm{kr}$.

I efterordet til det ofte omtalte, men sjældent læste, essay, "Kunstværket i dets tekniske reproducerbarheds tidsalder", skriver Walter Benjamin om forbindelserne mellem kunst og krig. Benjamins positive analyse af de nye reproduktionsteknologiers emancipatoriske potentiale - filmen og radioen muliggør en overskridelse af forældede overleverede idéer om kunst og deltagelse og peger ikke blot frem imod en kritisk, kollektiv omgang med kunst, men mod et nyt klasseløst samfund - forskydes og knyttes sammen med nazismens “æstetisering af politikken", hvor "masserne kommer til udtryk (men absolut ikke til deres ret)". En potentielt frigørende historisk udvikling slår om i det modsatte, og nazismen afsporer ikke blot det nye og konsoliderer de kapitalistiske produktionsforhold, men bruger det revolutionære opbrud destruktivt. "Alle bestræbelser på at æstetisere politikken kulminerer i ét punkt. Dette ene punkt er krigen”, skriver Benjamin advarende.

Benjamins tekst er skrevet før Nazi-Tysklands invasion af Polen (i 1939) og før koncentrationslejrene blev til egentlige udryddelseslejre (i 1941), men konturerne af det fascistiske projekt står ikke desto mindre helt klare for Benjamin, der på dette tidspunkt selv som tysk marxistisk jøde var flygtet fra Tyskland til Paris. Fascismen er dedikeret til krig og udryddelse, det stod klart for den kommunistiske avantgarde-kritiker. "Kun krigen gør det muligt at mobilisere alle vore dages tekniske hjælpemidler under opretholdelse af ejendomsforholdene." Benjamin genkender den nazistiske vilje til krig, fordi han allerede har set den i den italienske futurisme, der mere end tyve år tidligere besang krigens rensende destruktivitet og anskuede menneskehedens egen tilintetgørelse som et gesamtkunstværk. Med andre ord æstetiserede futuristerne død og ødelæggelse og forvandlede krigens destruktion til en art æstetisk begivenhed. Nazismen var dette projekt gennemført politisk.

Kunst er således ikke bare et politisk instrument for fascismen ifølge Benjamin. I fascismen bliver bestemte æstetiske forestillinger om sammenhæng og evighed til et æstetisk-politisk program, der skal realiseres politisk. Hitler er den ariske races kunstnerfører, der skal give folket form. Og fjerne det, der truer med at opløse den perfekte og evige form. Inklusive krig, og hvad Agamben kalder biopolitisk borgerkrig mod folket med lille f, alle dem der ikke passer til billedet af det suveræne og fuldt tilstedeværende folk, Folket. Det være sig jøderne, antitesen til den ariske race, handicappede, kommunister og alle, der ikke er en del af forestillingen om den selvnærværende ariske race. 
For Benjamin og Agamben er nazismen kulminationen på et særlig æstetisk-politisk projekt, der tager form af en uafbrudt krig, hvor staten er et kunstværk, og kunst udtrykker folkets essens. Forholdet mellem kunst og krig er således på ingen måde alene et spørgsmål om repræsentation i en simpel betydning, hvor kunstnere gengiver krigshandlinger.

\section{Kunst og krig}

Et sådant udvidet perspektiv på forholdet mellem kunst og krig finder vi også i den af den engelske historiker Joanna Bourkes redigerede antologi Art and War: A Visual History of Modern Conflict fra 2017. Bourke har selv ved flere lejligheder skrevet indsigtsfuldt om krig, og om hvordan krig tenderer til at sive ind i hverdagskulturen og militarisere den på forskellige måder, senest i bogen Wounding the World: How Military Violence and War-Play invades our Lives. Som bl.a. Hardt og Negri, Eyal Weizman, Derek Gregory og Jasbir Puar har argumenteret for, og som Bourke viser i Wounding the World, har instrumentaliseringen af truslen om islamisk terrorisme i Vesten resulteret i implementeringen af et egentligt antioprørsregime, hvor distinktionen mellem fred og krig er blevet usikker, og hvor krigen er tilstede som sikkerhedsforanstaltninger og en generaliseret usikkerhed.

I Bourkes nye antologi gennemgår kunsthistorikere, historikere, arkæologer, filmteoretikere og antropologer i 20 tekster, hvordan kunstnere har gengivet og forholdt sig til krig fra Krimkrigen til i dag. Der er kapitler om enkeltkunstnere, der har arbejdet indgående med krig som kunstnerisk tema, som Otto Dix og Nancy Spero, men der er også kapitler om, hvordan børn tegner krigshandlinger, eller hvordan krigsfanger har aflagt vidnesbyrd om deres oplevelser gennem tegninger, broderier og andre visuelle medier. Det er således ikke kun traditionelle højkulturelle kunstneriske repræsentationer af krig, hvordan kunstnere har afbildet krig enten propagandistisk eller kritisk, men også visuelle udtryk i en udvidet forstand, bogen beskæftiger sig med. Det er en af bogens styrker. Som undertitlen indikerer, er det derfor ikke kun kunst i snæver forstand, der er bogens fokus. Den handler om, hvordan krig forstås og opleves visuelt. Selvom flere af teksterne i bogen begrænser sig til at operere med en lidt snæver forståelse af det visuelle, hvor det stadigvæk er specifikke og klart afgrænsede objekter, og ofte kunstværker, der analyseres, så opererer antologien i eller peger hen imod et udvidet visuel kultur-felt, hvor krig og kunst ikke kun har at gøre med kunstneriske repræsentationer af krigshandlinger af forskellig slags. Hvad vi måske med Benjamin kan kalde et billedpolitisk rum, hvor kunst har at gøre med, hvordan vi deler det sanselige eller giver form og mening til det politiske rum, som henholdsvis Rancière og Claude Lefort ville formulere det. Så langt når antologien ikke, den er mere historisk end filosofisk og billedpolitisk. Og derfor når den aldrig frem til at undersøge sådan noget som forholdet mellem krig, statsdannelse, fællesskabsfølelser og kunst, hvad der ellers synes oplagt i den nuværende historiske konjunktur, antioprørsregimet in mente.

Vi er nok nødt til at gå lidt mere 'filosofisk' til værks, end Bourke og konsorter gør det, og forsøge at tage Benjamins fordring om udviklingen af en antifascistisk kunsthistorie på os. Altså forsøge at udvikle kunsthistoriske begreber, der er uanvendelige for fascismen. Det er ikke nogen helt nem opgave. Men opløsningen af forskellen på krig og fred nødvendiggør et nyt vokabularium, hvormed vi ikke blot kan redegøre for, hvordan 
krig er blevet til en administrationsmåde (fra Israel/Palæstina til ghettoerne i USA og visitationszoner i København), men også analysere politikkens æstetiske dimension og kunstens politiske kraft.

\section{Visuel forskel}

Det handler om dynamikken mellem (en fascistisk) æstetisering (af politikken) og (en revolutionær) politisering (af kunsten), som Benjamin skriver i sit kunstværkessay. De næsten tre tusind år gamle brutale og majestætiske relieffer på de assyriske kongers paladser i Nimrud og Ninive er måske nogen af de først eksempler på forbindelsen mellem krig og kunst, æstetisering og politisering. Reliefferne gengiver med stor vellyst nedslagtningen af de assyriske kongers fjender. Budskabet i reliefferne står lysende klart: de assyriske konger er verdens herskere. Reliefferne udgør et dekorativt program og bekræfter kongens legitimt opnåede magt. Fjenderne bliver ikke blot besejret, men ydmyget, og de bloddryppende detaljer er overvældende: spyddet bliver drevet ned i løvens gab, den besejrede fjende bliver halshugget, spiddet eller hængt og får flået huden af. Reliefferne er et tidligt visuelt vidnesbyrd om imperialisme, hvor assyrerne underlagde sig områder, der strakte sig fra Egypten til Den Persiske Golf.

Volden er allestedsnærværende i reliefferne, men formelle spil i reliefferne mellem afbillede elementer som våben, kropsdele og mønstre i tøj flytter beskuerens opmærksom væk fra den narrative vold "til voldsomheden i de mangfoldige kontakters mangfoldige former", som Leo Bersani formulerer det i en analyse af reliefferne. Der sker således en bevægelse mellem de voldelige emner og en vis formel differentiel reproduktion, hvor volden går fra at være en destruktiv fiksering til at blive noget andet, til at blive en åbenhed for et mere grundlæggende fravær af identitet som væren.

Den tyske fascisme, som Benjamin analyserede, var et desperat fors $\varnothing \mathrm{g}$ på at benægte denne differentielle eller urolige reproduktion, som et forsøg på at afvise fraværet af identitet, at vi ikke er noget, er vores identitet, tyskere, arier eller kunstneriske overmennesker, men at vi bare er, og at identitet er noget, vi har. Nazismens udryddelse af jøderne var et fors $\varnothing g$ på at benægte repræsentation til fordel for den komplette tilstedeværelse af den tyske race. Re-præsentationens forskel - repræsentationen er en præsenteret eller fremvist præsentation - blev fors $\varnothing$ gt erstattet af en total tilstedeværelse, hvor den jødiske anti-race, folket uden land, blev fjernet fra jordens overflade. Tilbage var kun den skabende kunstnerrace, arierne, uden forskel og mellemrum, totalt tilstede og helt nærværende. Den biopolitiske fraktur var helet, folket var blevet sig selv uden rest, politisk i hver en fiber af kroppen. Jøderne, de handikappede og kommunisterne var væk, fjernet fra universet. Det var som om, de aldrig havde været en del af folket.

Men det er de, jøderne, de handicappede, palæstinenserne, migranterne og muslimer bliver altid ved med at hjemsøge det politiske fællesskabs æstetiserede stat, uanset hvor meget den fører krig mod dem. Og derfor er det nødvendigt at gå imod de etniske og nationalistiske identiteter, der for alvor er på vej frem aktuelt, og forsøge at tænke sociale relationer hinsides identitet, tænke en form for ikke-identisk lighed hinsides fiktionen om det ukrænkelige subjekt og fællesskab. 